\title{
PERAN ORANG TUA SEBAGAI SUMBER PENDIDIKAN KARAKTER BAGI ANAK USIA DINI
}

\author{
M. Rezki Andhika \\ Sekolah Tinggi Agama Islam Negeri Teungku Dirundeng Meulaboh \\ Email: mr_andhika@staindirundeng.ac.id
}

\begin{abstract}
Abstrak
Tulisan ini mengkaji tentang peran orang tua sebagai sumber pendidikan karakter bagi anak usia dini. Kajian ini dilakukan dengan menggunakan metode studi pustaka (Library Research). Hasil dari studi ini menunjukkan bahwa peran orang tua menjadi faktor penentu bagi perkembangan anak baik fisik maupun mental adalah peran kedua orang tua sebagai pendidik pertama dan utama bagi anak-anak yang dilahirkan sampai dia dewasa. Dalam proses pembentukan pengetahuan, melalui berbagai pola asuh yang disampaikan oleh orang tua sangatlah penting. Pendidikan dalam keluarga sangat berperan dalam mengembangkan watak, kepribadian, nilai-nilai budaya, nilai-nilai keagamaan dan moral serta ketrampilan sederhana anak. Peran sebagai orang tua dalam mempengaruhi karakter anak tidak lagi hanya dibebankan kepada ibu saja. Peran ayah dalam pembentukan karakter anak sangat besar. Ayah tetap wajib ikut menjaga interaksi dengan anaknya, seperti mengajaknya berbicara, bercanda, dan bermain.
\end{abstract}

Kata kunci: Peran Orang Tua, Anak Usia Dini, Pendidikan Karakter

\begin{abstract}
This paper examines the role of parents as a source of character education for early childhood. This study was conducted using the library research method. The results of this study indicate that the role of parents is a determining factor for children's development, both physically and mentally, is the role of both parents as the first and main educators for children who are born until they are adults. In the process of forming knowledge, various parenting styles conveyed by parents are very important. Education in the family plays a very important role in developing the character, personality, cultural values, religious and moral values, and simple skills of children. The role of parents in influencing the character of children is no longer borne by the mother only. The role of the father in shaping the character of the child is very large. Fathers are still obliged to participate in maintaining interactions with their children, such as inviting them to talk, joke, and play.
\end{abstract}

Keywords: The Role of Parents, Character Education, Early Childhood 


\section{A. PENDAHULUAN}

Pendidikan saat ini bukan hanya dipandang pada bertambah jumlah kuantitas peserta didik, namun juga kepada kualitasnya. Tantangan pendidikan dalam menghadapi kondisi peserta didik yang semakin mengkhawatirkan. Moral dan sopan santun peserta didik kita sangat rendah. Banyaknya kasus pelajar yang kerap kali melakukan tawuran, tindak kekerasan atau bullying oleh pelajar, bahkan sampai pada pergaulan bebas di kalangan pelajar. Hal ini patut dicurigai merupakan penyebab dari kurangnya etika dan moral yang ada pada pelajar itu sendiri. Pendidikan sejatinya merupakan sebuah usaha sadar dalam menumbuhkan dan mengembangkan fitrah manusia sesuai dengan nilai-nilai yang telah ada di masyarakat. Pendidikan juga merupakan sebuah bentuk pembelajaran keterampilan, pengetahuan, serta kebiasaan sekelompok individu yang secara turun-menurun dari generasi kepada generasi selanjutnya dengan cara pengajaran, pelatihan serta penelitian.

Adapun pendidikan ini terkadang terjadi dengan sebab adanya bimbingan dari orang lain, terkadang juga terjadi secara otodidak atau tanpa bimbingan dan petunjuk orang lain. Hal tersebut menunjukkan bahwa karakter kehidupan tempat anak tumbuh sangat mempengaruhi karakter anak itu sendiri, terutama lingkungan keluarga yang merupakan wadah pendidikan awal dan utama dalam pertumbuhan seorang anak, karena anak lebih banyak waktunya bersama keluarga. Keluarga memberi dasar penting dalam membentukan karakter anak. Keluarga merupakan miniatur dari masyarakat luas, disinilah anak-anak pertama sekali mendapatkan bimbingan secara mendasar pendidikan nilai dari kedua orang tuanya sebelum anak tersebut bergaul dan berhadapan dengan masyarakat luas.

Pembentukan karakter anak dapat dilakukan dengan cara menanamkan nilai-nilai karakter secara konsisten baik ketika anak berada dalam lingkungan keluarga, lingkungan sekolah, maupun lingkungan masyarakat. Dengan adanya konsistensi tersebut, karakter yang diharapkan dapat tertananam dengan baik sehingga terbentuk kakrakter yang baik (Kurniawan, 2015: 1).

Anak akan memiliki karakter yang baik dan kuat bila proses pendidikan karakter yang diterapkan oleh kedua orang tua dalam keluarga dilakukan dengan tepat dan baik, begitu juga sebaliknya. Karena keluarga merupakan lingkungan pertama bagi anak yang di dalamnya anak tumbuh dan berkembang baik fisik maupun mental, serta psiko sosial dengan cara menyerap dan meniru semua yang dilihat dan didengar. Kemudian dengan meningkatnya usia, anak akan mengenal teman sebaya dari lingkungan tetangga. Anak sudah mampu mengambil sisi baik dari hubungannya dengan teman dekatnya dan dapat merasakan aman dan nyaman dalam hangatnya keluarga dan teman-temannya. Selanjutnya anak akan masuk lingkungan sekolah, dimana mereka akan mengenal lebih banyak teman. Anak merasa senang bisa bergabung ke dalam bagian dari sebuah kelompok sosial, dan membuat anak memiliki rasa bahwa pendapat temantemannya merupakan hal yang dianggap penting. Namun sering kali tekanan dari temantemannya bisa menjadi masalah, terkadang membuat anak melakukan perilaku berbohong maupun melakukan perilaku salah lainnya untuk menyelaraskan pendapat teman-temannya yang dianggap penting tersebut. Disini anak memerlukan bimbingan pemahaman prilaku lebih lanjut agar ia paham mana perilaku yang dianggang boleh dilakukan atau tidak boleh. Maka dapat disimpulkan bahwa akhlak dan prilaku anak bergantung pada lingkungan, bila lingkungan 
tempat berada si anak baik, maka berpotensi baik pula prilaku anak, begitu juga sebaliknya (Saputra, 2017: 230).

Anak yang umumnya berusia di bawah 8 tahun sangat membutuhkan arahan, bimbingan, tuntunan dan contoh yang baik dari orang tua dalam pertumbuhan dan perkembangan pondasi dasar kepribadian yang seimbang, utuh dan selaras dengan nilai-nilai kehidupan yang ada dalam masyarakat luas, sehingga anak bukan hanya mengetahui nilai-nilai karakter yang ada dalam masyarakat, tetapi juga dapat menerapkannya dalam kehidupan bersosialnya. Anak diibaratkan sebagai kertas putih, yang menentukan kertas tersebut tetap putih atau tidak hanyalah orang tua. Fenomena yang dialami sekarang oleh sejumlah besar dalam pendidikan dimana orang tua menyerah tugas seutuhnya kepada sekolah. Justru itu membuat karakter anak terbentuk dengan tidak baik, disebabkan tidak terjalin kesinambungan atau penguatan karakter yang telah ditanam oleh guru di sekolah, apabila anak berada di luar lingkungan dan jam sekolah.

\section{B. HASIL DAN PEMBAHASAN}

\section{Pendidikan Karakter}

Dalam kamus psikologi dinyatakan bahwa karakter adalah kepribadian ditinjau dari titik tolak etis dan moral, misalnya kejujuran seseorang, biasanya mempunyai sifat-sifat yang relatif tepat. (Aziz, 2011:197-198). Mengukir itu sendiri adalah suatu kegiatan membuat gambar atau ukiran pada suatu kayu atau batu. Karakter juga dapat diartikan sebagai sifat-sifat kejiwaan, budi pekerti atau akhlak, tabiat, watak, yang menjadi pembeda seseorang dengan orang lain (Elmubarok, 2007: 102).

Merujuk kepada beberapa pengertian di atas maka dapat diartikan bahwa kepribadian merupakan suatu istilah yang diarahkan pada penerapan nilai-nilai luhur dalam bentuk prilaku yang sama dengan moralitas. Kepribadian adalah nilai-nilai tingkah laku manusia yang melingkupi segala aktivitas manusia, baik yang berkaitan manusia dengan Tuhannya, dengan dirinya sendiri, atau manuia dengan sesama manusia, serta manusia dengan lingkungannya, yang diwujudkan dalam bentuk pikiran, perasaan, perkataan, sikap, atau tindakan yang berdasarkan pada Agama, Norma dan sistem karma, hukum, budaya, dan adat istiadat.

Nilai-nilai kebaikan yang mewakili kepribadian tersebut dapat berupa nilai-nilai dalam ajaran agama dan nilai-nilai yang telah ada dalam kehidupan sosial. Jika seseorang mampu menerapkan nilai-nilai tersebut dalam kehidupan bermasyarakat sehari-hari, maka orang tersebut dapat dikatakan memiliki karakter atau orang yang berkarakter, begitu juga terhadap anak-anak. Secara sederhana, kepribadian merupakan karakteristik yang melekat pada diri manusia semenjak ia lahir dan dibentuk oleh proses belajar sepanjang hayat.

Pendidikan merupakan adalah suatu proses perubahan tingkah laku manusia, sedangkan karakter merupakan sebagai ciri khas/identitas yang melekat pada manusia. Lickona (Muchlas Samani, 2012: 44) menguraikan pendidikan karakter kepada suatu upaya yang dirancang secara sengaja untuk memperbaiki karkater para siswa. Sedangkan menurut Scerenko (Muchlas Samani, 2012:45) mengartikan pendidikan karakter sebagai upaya yang sungguh-sungguh dengan cara mencari kepribadian yang positif kemudian dikembangkan, didorong dan diberdayakan melalui keteladanan, kajian, serta praktek emulasi yang merupakan usaha maksimal untuk mewujudkan hikmah dari apa-apa yang diamati dan dipelajari. 
Pendidikan karakter bukan sekedar mengajarkan mana yang benar dan mana yang salah, lebih dari itu, pendidikan karakter menanamkan kebiasaan (habituation) tentang hal mana yang baik sehingga anak-anak menjadi paham (kognitif) tentang mana yang benar dan salah, mampu merasakan (afektif) nilai yang baik dan biasa melakukannya (psikomotor). Dengan kata lain, pendidikan karakter yang baik harus melibatkan bukan saja aspek "pengetahuan yang baik" (moral knowing), akan tetapi juga "merasakan dengan baik" (moral feeling), dan "perilaku yang baik" (moral action) (Permono, 2013:1).

Pendidikan karakter merupakan sebuah usaha penanaman kebiasaan berupa sikap atau perilaku yang baik sehingga seorang individu paham dan mampu merasakan serta melaksanakannya. Adapun penanaman kebiasaan baik pada anak dengan pendidikan karakter bagaimana pendapat Ratna Megawangi tentang sembilan pilar karakter adalah sebagai berikut:

a. Perilaku cinta Tuhan dan kebenaran;

b. Sikap tanggungjawab, disiplin dan kemandirian;

c. Sikap amanah;

d. Perilaku hormat dan santun;

e. Sikap kasih sayang, kepedulian, dan kerjasama;

f. Sikap percaya diri, kreatif, dan pantang menyerah;

g. Perilaku adil dan kepemimpinan;

h. Sikap baik dan rendah hati;

i. Perilaku toleransi dan cinta damai.

Sembilan karakter tersebut menjadi hal mendasar yang harus ditanamkan kepada anak sejak usia dini. Dengan harapan kelak anak menjadi orang yang berguna bagi sesama, tangguh dan berjiwa kuat dalam menghadapi tantangan di masa yang akan datang. Penanaman nilai karakter tersebut semestinya berawal dalam lingkungan pertama anak yaitu keluarga. Maka peran orang tua dalam keluarga adalah sebagai pondasi dasar nilai karakter anak untuk dapat berkembang di dalam kehidupan dalam masyarakat.

Pendidikan karakter memiliki makna lebih tinggi dari pendidikan moral karena pendidikan karakter tidak hanya berkaitan dengan benar atau salah, akan tetapi bagai-mana menanamkan kebiasaan tentang hal-hal yang baik dalam kehidupan sehingga anak memiliki kesadaran dan pemahaman yang tinggi serta kepedulian dan komit-men untuk menetapkan kebajikan dalam kehidupan sehari-hari (Harun, 2013:303).

\section{Kapan Pendidikan Anak Dimulai}

Sebagaimana penjelasan pada pendahuluan, anak usia dini berumur di bawah 8 tahun sangat membutuhkan arahan, bimbingan dan tuntunan agar anak tidak hanya mengetahui nilai karakter dalam masyarakat, tetapi juga mampu menerapkannya dalam kehidupan sehari-hari. Namun seringkali orang tua keliru yang beranggapan bahwa mendidik karakter anak baru bisa dimulai setelah anak menyelesaikan pendidikan sekolah dasar. Nytanya pendidikan karakter yang dimulai usia taman kanak-kanakpun sebenarnya sudah terlambat. Dasar pendidikan karakter sebaiknya dimulai dari masa balita atau usia emas (Golden Age) ketika anak berusia 0 sampai 5 tahun, karena ketika anak berada pada usia ini terbukti sangat menentukan kemampuan anak dalam mengembangkan potensinya. Dari hasil penelitian menunjukkan bahwa sekitar 50\% variabiitas kecerdasan orang dewasa sudah terjadi ketika anak berusia 4 tahun. Peningkatan 30\% 
berikutnya terjadi pada usia 8 tahun, dan 20\% sisanya pada pertengahan atau akhir dasawarsa merupakan lingkungan pertama bagi pertumbuhan karakter anak. Selain itu, Saat usia dini, lebih mudah membentuk karakter anak (Rustini, 2012). Karena anak lebih cepat menyerap perilaku dari lingkungan sekitarnya. Pada usia ini, perkembangan mental berlangsung sangat cepat. Oleh karena itu, lingkungan yang baik akan membentuk karakter yang positif. Pengalaman anak pada tahun pertama kehidupannya sangat menentukan apakah ia akan mampu menghadapi tantangan dalam kehidupannya dan apakah ia akan menunjukkan semangat tinggi untuk belajar dan berhasil dalam pekerjaannya.

Sejalan dengan itu, dalam perkembangan kognisi menurut Piaget, anak usia dini masuk dalam fase sensorymotor ( $0-2$ tahun) sampai fase perkembangan pra operasional ( $2-7$ tahun). Oleh karena itu, anak usia dini sangat mudah meniru dan menyerap apa yang di dapatkan dari lingkungan sekitar dimana dia tumbuh, lingkungan yang baik akan berpengaruh baik kepada anak, begitupula sebaliknya, lingkungan yang tidak baik akan berpengaruh tidak baik pula pada anak (Ditha Prasanti, 2018: 14-15).

Masa usia dini adalah masa keemasan, artinya masa tersebut merupakan masa terbaik dalam proses belajar yang hanya sekali dan tidak pernah akan terulang kembali. Pada masa ini, pertumbuhan dan perkembangan anak berlangsung sangat cepat dan menjadi penentu terhadap karakter anak kelak. Jika otak anak pada usia ini tidak mendapat stimulasi yang maksimal, maka perkembangan fisik dan mental anak tidak akan berkembang secara optimal. Peran orang tua sebagai guru pertama dan utama dalam keluarga sangat penting untuk dimaksimalkan dan dimanfaatkan pada masa ini, dan peran tersebut tidak dapat digantikan oleh siapapun.

Peran orang tua sangat penting dalam membentuk karakter anak agar nantinya siap menghadapi dunia di masa depan. Pada masa ini, anak akan meniru perilaku orang tua, karena orang tua adalah orang pertama yang dekat dan dikagumi oleh anak. Selain itu, lingkungan keluarga juga mempengaruhi pembentukan kepribadian anak, karena pada masa ini anak banyak menghabiskan waktu di lingkungan keluarga. Hal ini terlihat dari cara seorang anak berpakaian, bersikap dan bertingkah laku sehari-hari yang biasanya tidak jauh berbeda dengan lingkungan keluarga.

\section{Peran Keluarga}

Faktor penentu perkembangan fisik dan mental anak adalah peran kedua orang tua sebagai pendidik pertama dan utama bagi anak yang lahir hingga dewasa. Dalam proses pembentukan pengetahuan, melalui berbagai metode parenting yang ditularkan oleh orang tua, sangatlah penting. Pendidikan dalam keluarga memegang peranan yang sangat penting dalam pengembangan kepribadian, karakter, nilai budaya, nilai agama dan moral serta keterampilan sederhana.

Searah dengan penjelasan di atas, Thomas Lickona mengatakan bahwa secara umum orang-orang memandang keluarga merupakan sumber pendidikan moral yang paling utama bagi anak-anak. Mereka adalah guru pertama dalam mendidik moral. Hubungan antar orang tua dan anak dipengaruhi dengan berbagai perbedaan khusus dalam hal emosi, yang menyebabkan anak merasakan dicintai dan dihargai atau sebaliknya (Lickona, 2016: 48).

Dengan demikian kondisi dalam keluarga ikut berpengaruh terhadap pendidikan karakter seorang anak, suasana keluarga tanpa kekerasan menjadi salah satu solusi yang sangat efektif untuk membuat seorang anak merasa nyaman, damai dan tenreram apabila berada di rumahnya, 
akhirnya anak memiki emosi yang stabil sehingga karakter yang baik akan terbentuk. Orang tua memiliki banyak peran dalam mempengaruhi pola pikir dan perilaku dari seorang anak. Adapun bentuk peran dari orang tua sebagai berikut:

a. Orang tua dapat memberikan penjelasan mengenai hal baik dan buruk bagi anak, penting bagi anak untuk mendapat penjelasan terhadap kelakuan itu boleh dilakukan atau tidak dengan kata yang mudah mengerti.

b. Pendidikan yang keras juga akan menyebabkan karakter anak menjadi keras, walaupun menggunakan gaya belajar yang keras akan mendisiplinkan anak, tetapi juga akan meningkatkan kemungkinan anak menjadi tidak nyaman.

c. Apa yang dilakukan orang tua akan ditiru oleh anak, anak akan mengikuti apa yang menjadikan kebiasaan orang tuanya. Jadi dalam mendidik anak untuk memiliki karakter yang baik, orang tua harus memberi contoh yang positif kepada anak baik dalam tingkah laku atau berbicara.

d. Orang tua harus dapat melindungi anaknya dari lingkungan sosial yang buruk. Jika orang tua telah mendidik anaknya dengan baik, maka orang tua harus dapat menjaga atau mengawasi anaknya dalam kehidupan bermasyarakat.

e. Memberi kasih sayang dan dorongan semangat, orang tua harus mencurahkan kasih sayang dan rasa hormat kepada anak, baik ketika mereka mendapatkan nilai ujian yang baik maupun ketika mereka tidak mendapatkan hasil yang diinginkan karena mereka telah bekerja sangat keras.

Apabila dikaitkan dengan hak- hak anak, menurut (Sugiharti, 2005:16) tugas dan tanggung jawab orang tua antara lain:

a. Bertanggungjawab untuk mengasuh dengan penuh rasa kasih sayang sejak anak dilahirkan.

b. Menjaga dan memelihara kesehatan anak.

c. Menyedikan alat-alat permainan, ruang dan kesempatan untuk bermain.

d. Memberi pendidikan sesuai dengan minat dan bakat yang dimiliki anak.

e. Menanam pendidikan keagamaan serta melindungi anak tindak kekerasan dari luar.

f. Memberikan kesempatan anak untuk mengembangkan dan berpendapat sesuai dengan usia anak.

Peran sebagai orang tua dalam mempengaruhi karakter anak tidak lagi hanya dibebankan kepada ibu saja. Peran ayah dalam pembentukan karakter anak sangan besar. Anggapan bahwa tugas seorang ayah bekerja mencari uang dan ibu mengasuh anak dan mengurus rumah tangga, namun peran ayah dalam mengasuh atau merawat dan mendidik anak-anak tetap diperlukan. Anggapan ini memang kelihatan ideal, tetapi pada praktiknya tak bisa diterapkan secara kaku. Sebaiknya ayah tetap wajib ikut menjaga interaksi dengan anaknya, seperti mengajaknya berbicara, bercanda, dan bermain. Anak yang masih kecil jelas tidak bisa dilepaskan dari sosok ayahnya.

Adapun peran yang dilakukan orangtua dalam membentuk karakter kepada anak dilakukan dengan cara sebagai berikut (Widianto, 2015:35):

a. Menanamkan nilai kebaikan kepada anak. Menanamkan konsep diri pada anak secara alami kepada anak tanpa harus direncanakan terlebih dahulu. 
b. Menggunakan cara yang membuat anak memiliki keinginan untuk berbuat baik. Peran yang dilakukan orangtua dilakukan dengan cara memberikan beberapa contoh kepada anak mengenai karakter yang sedang dibangun.

c. Mengembangkan sikap mencintai perbuatan yang baik. Supaya anak mengembangkan karakter yang baik, maka perlu ada penghargaan bagi anak yang membiasakan melakukan kebaikan. Begitu pula dengan anak yang melakukan pelanggaran, supaya diberi hukuman yang bersifat mendidik.

d. Melaksanakan perbuatan baik. Karakter yang sudah mulai dibangun melalui konsep diaplikasikan dalam proses pembelajaran informal dalam keluarga. Selain itu, orangtua juga tetap memantau perkembangan anak dalam praktik pembangunan karakter di rumah. Orangtua bagi si anak akan dianggap model. Segala tingkah laku orangtua akan diadopsi oleh si anak. Apa yang dilakukan oleh orangtua, bisa jadi dianggap benar oleh anak. Untuk itulah, orangtua harus mampu memberikan contoh yang positif.

Rosikum membagi peran seorang ayah dan ibu dalam pembentukan katekter anak. Seorang ayah dalam keluarga memiliki beberapa peranan sebagai berikut (Rosikum, 2018: 299$300)$ :

a. Sebagai teman setia bagi anaknya.

b. Memenuhi nafkah keluarga.

c. Mengembangkan potensi yang ada pada anak sekaligus sebagai guru bagi anak.

d. Sebagai contoh kepribadian, kasih sayang, perilaku dan moralitas kepada anak.

e. Ayah sebagai pengaruh yang mantap kepada anak dalam menuju tahap kedewasaan.

f. Sebagai filter dan pemantau perilaku sosial anak.

g. Sebagai konselor dan teman bagi anak manja.

Berbeda dengan sosok ayah, seorang ibu pada umumnya lebih berperan sebagai penjaga keselamatan dan kesehatan anak, serta pendidik dasar bagi anaknya. Peranan seorang ibu dipengaruhi atas dasar norma, kebudayaan, golongan sosial, dan jenis sosialisasi yang diterima. Sehingga banyak variasi yang luas dalam manifestasi perilaku yang ditibulkan oleh ibu kepada anaknya.

\section{Kesalahan pola asuh orang tua}

Dari paparan di atas jelas bahwa orang tua memiliki banyak peran dalam mempengaruhi pola pikir dan perilaku dari seorang anak. Kesalahan dalam pengasuhan anak akan berakibat pada kegagalan dalam pembentukan karakter yang baik. Menurut Megawangi, sebagai mana dikutip oleh (Suarmini, 2014:276), beberapa yang dapat mempengaruhi perkembangan kecerdasan emosi anak sehingga berakibat pada pembentukan karakternya disebabkan oleh kesalahan dari orang tua dalam mendidik anak, yaitu:

a. Kurangnya ekspresi verbal dan fisik dari kasih sayang.

b. Tidak meluangkan cukup waktu untuk anak-anak mereka.

c. Pelecehan verbal, seperti mengisyaratkan dan meremehkan anak-anak dan mengucapkan kata-kata kasar.

d. Penganiayaan fisik, seperti memukul, mencubit, dan hukuman fisik lainnya.

e. Memaksa anak untuk menguasai kemampuan kognitif sejak dini.

f. Jangan menanamkan "sopan santun" pada anak-anak. 
Menurut Megawangi, pengaruh pola asuh jenis ini akan mengakibatkan anak memiliki kepribadian bermasalah atau memiliki kecerdasan emosional yang rendah.

a. Anak menjadi acuh tak acuh, tidak membutuhkan orang lain, dan tidak menerima persahabatan. Karena dia menderita kemarahan masa kecil, ketidakpercayaan dan gangguan emosional negatif lainnya. Seiring bertambahnya usia, dia akan menolak dukungan, simpati, cinta, dan tanggapan positif lainnya di sekitarnya. Dia terlihat sangat mandiri, tapi dia tidak hangat dan di benci oleh orang lain.

b. Tidak tanggap secara emosional, karena anak yang ditolak tidak akan mampu memberikan kasih sayang kepada orang lain.

c. Perilaku agresif yaitu selalu ingin menyakiti orang secara verbal dan fisik.

d. Merasa tidak aman dan merasa tidak berharga dan berguna.

e. Anda selalu memiliki pandangan negatif terhadap lingkungan sekitar, seperti merasa tidak aman, cemas, tidak aman, curiga terhadap orang lain dan perasaan bahwa orang lain mengkritiknya.

f. Ketidakstabilan emosional, yaitu intoleransi atau kurangnya ketahanan terhadap stres, mudah tersinggung, mudah tersinggung dan tidak dapat diprediksi dari orang lain.

g. Keseimbangan antara perkembangan emosional dan intelektual. Dampak negatif lainnya bisa berupa studi tentang mogok, bahkan bisa berujung pada kenakalan, pertengkaran, dan lain-lain.

Orang tua yang merasa tidak aman dan terlalu menekan anak akan membuat anak merasa tidak nyaman, dan tidak akan menjadikan orang tua sebagai "role model". Anak-anak akan lebih mempercayai "peer group" mereka sehingga mereka mudah terpengaruh oleh pergaulan negatif.

\section{KESIMPULAN}

Peran orang tua menjadi sangat penting dalam pembentukan karakter anak untuk siap menghadapi dunia di masa yang akan datang. Anak akan meniru perilaku orang tua, karena orang tua adalah orang pertama yang dekat dan dikagumi oleh anak. Lingkungan keluarga berpengaruh dalam pembentukan karakter anak, karena anak pada masa ini banyak menghabiskan waktu di lingkungan keluarga. Hal ini dapat terlihat dari cara berpakaian, bersikap, dan berperilaku seharihari seorang anak yang biasanya tidak jauh berbeda dengan orang-orang yang ada dalam lingkungan keluarga.

Hasil dari beberapa penelitian menunjukkan bahwa separuh dari variabiitas kecerdasan seorang orang dewasa sudah terbentuk pada anak usia 4 tahun. Peningkatan 30\% selanjutnya terbentuk ketika anak berusia 8 tahun, dan penyempurnaan sebesar $20 \%$ sisanya pada akhir usia sepuluh tahun, yang merupakan penyerapan dari lingkungan keluarga bagi pertumbuhan karakter anak. Selain itu, Saat usia dini, lebih mudah membentuk karakter anak. Karena anak lebih cepat menyerap perilaku dari lingkungan sekitarnya. Pada masa ini anak akan meniru perilaku orang tua, karena orang tua adalah orang pertama yang dekat dan dikagumi oleh anak. Pada usia ini, perkembangan mental berlangsung sangat cepat. Oleh karena itu, lingkungan yang baik akan membentuk karakter yang positif.

Dengan demikian kondisi dalam keluarga ikut berpengaruh terhadap pendidikan karakter seorang anak, suasana keluarga tanpa kekerasan menjadi salah satu solusi yang sangat efektif 
untuk membuat seorang anak merasa nyaman, damai dan tenreram apabila berada di rumahnya, akhirnya anak memiki emosi yang stabil sehingga karakter yang baik akan terbentuk. Orang tua memiliki banyak peran dalam mempengaruhi pola pikir dan perilaku dari seorang anak. Adapun bentuk peran dari orang tua adalah: 1) memberikan penjelasan mengenai hal baik dan buruk bagi anak, penting bagi anak untuk mendapat penjelasan terhadap kelakuan itu boleh dilakukan atau tidak dengan kata yang mudah mengerti, 2) Segala perilaku orang tua akan ditiru dan diikuti oleh anak apa yang menjadikan kebiasaan orang tuanya. Jadi orang tua harus memberi contoh yang positif kepada anak baik dalam tingkah laku atau bertuturkata, 3) Orang tua perlu menjaga dan mengawasi anak dari lingkungan social yang buruk, serta mencurahkan rasa kasih sayang dan semangat, dan menghargai anak di saat mereka mendapatkan nilai ujian yang bagus maupun ketika mereka tidak mendapat hasil yang diinginkan.

\section{DAFTAR PUSTAKA}

Abdul Muhaimin. (2017). Strategi Pendidikan Karakter Perspektif Kh. Hasyim Asy'ari. Nidhomul Haq: Jurnal Manajemen Pendidikan Islam, 26-37.

Aziz, H. A. (2011). Pendidikan Karakter Berpusat Pada Hati. Jakarta: Al-Mawardi Prima.

Elmubarok, Z. (2009). Membumikan Pendidikan Nilai. Bandung: Alfabeta.

Harun, C. Z. (2013). Manajemen pendidikan karakter. Jurnal pendidikan karakter, (3).

Kurniawan, M. I. (2015). Tri pusat pendidikan sebagai sarana pendidikan karakter anak sekolah dasar. PEDAGOGIA: Jurnal Pendidikan, 4(1), 41-49.

Lickona, T. (2016). Educating for Character. Jakarta: Bumi Aksara.

Ma arif, M. A., \& Rofiq, M. H. (2018). The Role of Islamic Education Teachers in Improving the Character of Nationalism in Boarding School. EDUKASI: Jurnal Pendidikan Islam, 64-78.

Megawangi, R. (2013). Pendidikan Karakter untuk Membangun Masyarakat Madani. Jakarta: IPPK Indonesia Heritage Foundation.

Ormrod, J. E. (2008). Psikologi Pendidikan Membantu Siswa tumbuh dan berkembang. Jakarta: Erlangga.

Permono, H. (2013). Peran orangtua dalam optimalisasi tumbuh kembang anak untuk membangun karakter anak usia dini.

Rosikum. (2018). Peran Keluarga dalam Implementasi Pendidikan Karakter Religius Anak. Jurnal Kependidikan, 293-308.

Rustini, T. (2012). Pendidikan Karakter Anak Usia Dini. Cakrawala Dini: Jurnal Pendidikan Anak Usia Dini.

Saputra, F. (2017). Pengaruh Lingkungan Tempat Tinggal Terhadap Prilaku Anak. At-Ta'dib, 225-245.

Sugiharti, S. (2005). Penjajagan Kebutuhan Tentang Pemenuhan Hak Anak. Yogyakarta: Balitbang BKKBN DIY.

Widianto, E. (2015). Peran Orangtua Dalam Meningkatkan Pendidikan Karakter Anak Usia Dini Dalam Keluarga. Jurnal PG-PAUD Trunojoyo: Jurnal Pendidikan dan Pembelajaran Anak Usia Dini, 2(1), 31-39. 